\title{
Impact of COVID-19 on ischemic stroke care in Hungary
}

\author{
Péter Pál Böjti (iD · Géza Szilágyi • Balázs Dobi (D) Rita Stang (D) István Szikora (D) Balázs Kis •

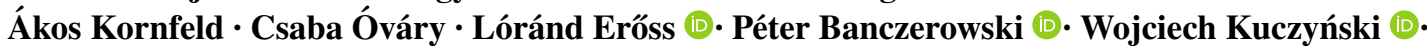 \\ Dániel Bereczki
}

Received: 6 May 2021 / Accepted: 20 July 2021 / Published online: 18 August 2021

(C) The Author(s) 2021

\begin{abstract}
Data about the coronavirus disease 2019 (COVID-19) pandemic's collateral damage on ischemic stroke (IS) care during the second epidemic wave in Central Europe are limited. We sought to evaluate the impact of the COVID-19 outbreak on Hungarian IS care during the two epidemic waves. This retrospective observational study was based on
\end{abstract}

Supplementary Information The online version contains supplementary material available at https://doi. org/10.1007/s11357-021-00424-z.

P. P. Böjti $(\bowtie) \cdot$ G. Szilágyi · R. Stang · I. Szikora ·

L. Erôss · P. Banczerowski · D. Bereczki

János Szentágothai Doctoral School of Neurosciences,

Semmelweis University, Balassa utca 6., Budapest 1083, Hungary

e-mail: bojtipeterpal@gmail.com

G. Szilágyi

e-mail: drszilagyig@gmail.com

R. Stang

e-mail: stang.rita@med.semmelweis-univ.hu

D. Bereczki

e-mail: bereczki.daniel@med.semmelweis-univ.hu

P. P. Böjti · I. Szikora · B. Kis · Á. Kornfeld · C. Óváry ·

L. Erôss $\cdot$ P. Banczerowski

National Institute of Mental Health, Neurology

and Neurosurgery, Budapest, Hungary

e-mail: h13424szi@ella.hue-mail: blazsejdoktor@

gmail.come-mail: kornfeld.akos@gmail.come-mail:

ovarycsaba@me.come-mail: 1.g.eross@gmail.come-mail:

bancpet@gmail.com

e-mail: h13424szi@ella.hu a nationwide reimbursement database that encompasses all IS admissions and all reperfusion interventions, i.e., intravenous thrombolysis (IVT) and endovascular therapy (EVT) from 2 January 2017 to 31 December 2020 in Hungary. COVID-19 pandemic's effect on the number of IS admissions and reperfusion interventions were analyzed using different statistics: means, medians, trends, relative rates, and linear relationships. The mean and median values of IS admissions and reperfusion interventions decreased

B. Kis

e-mail: blazsejdoktor@gmail.com

Á. Kornfeld

e-mail: kornfeld.akos@gmail.com

C. Óváry

e-mail: ovarycsaba@me.com

L. Erôss

e-mail: 1.g.eross@gmail.com

P. Banczerowski

e-mail: bancpet@gmail.com

G. Szilágyi

Department of Neurology, Medical Centre, Hungarian

Defence Forces, Budapest, Hungary

B. Dobi $\cdot$ R. Stang

Department of Probability Theory and Statistics, Eötvös

Loránd University, Budapest, Hungary

e-mail: balazs.dobi@gmail.com 
only in some measure during the COVID-periods. However, trend analysis demonstrated a significant decline from the trends. The decline's dynamic and amplitude have differed for each variable. In contrast to IVT, the number of IS admissions and EVTs negatively correlated with the epidemic waves' amplitude. Besides, the decrease in the number of IS admissions was more pronounced than the decrease in the number of reperfusion interventions. Our study demonstrated a significant disruption in IS care during the COVID-19 epidemic in Hungary, in which multiple different factors might play a role. The disproportionate reduction of IS admission numbers could partially be explained by the effect of health emergency operative measures and changes in patients' social behavior. Further studies are needed to evaluate the causes of our observations.

Keywords COVID-19 $\cdot$ Hungary $\cdot$ Stroke $\cdot$ Thrombolysis · Thrombectomy · Epidemiology

\section{Introduction}

Cerebrovascular diseases are the second leading cause of death worldwide. Up to $50 \%$ of stroke survivors are chronically disabled, which causes a tremendous public health burden with severe economic and social consequences [1]. Over the past decade, the treatment of acute ischemic stroke

B. Dobi · D. Bereczki

Neuroepidemiology Research Group ELKH, MTA-SE, Budapest, Hungary

I. Szikora · L. Erôss · P. Banczerowski

Department of Neurosurgery, Semmelweis University, Budapest, Hungary

W. Kuczyński

Department of Sleep Medicine and Metabolic Disorders, Medical University of Lodz, Lodz, Poland e-mail: darth.kuczas@gmail.com

D. Bereczki

Department of Neurology, Semmelweis University, Budapest, Hungary

D. Bereczki

European Academy of Neurology, EANcore COVID-19

Task Force, Vienna, Austria
(IS) has undergone fundamental changes due to the high-quality evidence that shows reperfusion interventions (intravenous thrombolysis, mechanical thrombectomy) within the 4.5 or $6 \mathrm{~h}$ of stroke onset can reduce the risk of death or disability and improve functional outcome. In recent years, the range of acute IS patients eligible for reperfusion interventions has further expanded as studies showed that these treatments could be used effectively up to $24 \mathrm{~h}$ after symptom onset in certain cases [2-9].

Coronavirus disease 2019 (COVID-19) pandemic reached Hungary on 4 March 2020, and by the end of May 2021, with the 83 thousand cumulative COVID19 cases per million people, Hungary was one of the most severely affected countries in Europe and the European Union. Considering the COVID-19 outbreak's extent in neighboring countries, Hungary is in the middle of the range in the Central European region. The impact of the ongoing epidemic on the Hungarian population is further emphasized by the particularly high number of COVID-19 deaths (3000 deaths per million people by the end of May 2021). It is important to note that testing capacities and case definitions influence the number of COVID-19 cases and COVID-19 related deaths. Therefore further adjustment might be needed for accurate comparison between countries [10-13].

With a wide range of variations, studies from all countries reported some negative impact of the COVID-19 pandemic on IS care [14-36]. Although some centers did not observe changes in the number of IS admissions, the vast majority of studies showed a remarkable decrease, with or without a significant decline in the number of reperfusion interventions [14, 18-20, 22-24, 26-28, 31-33, 35]. Data about the impact of the COVID-19 pandemic on IS care of Central Europe are limited. To date, two regional studies from Poland and Hungary demonstrated a marked reduction in the number of IS admissions and reperfusion treatments during the first wave of the SARS-CoV-2 (severe acute respiratory syndrome coronavirus 2) epidemic [17, 30]. The effect of the second wave of the COVID-19 pandemic on IS care is unknown in the current literature. In Hungary, the second wave of the COVID-19 outbreak was different from the first wave: the number of SARS-CoV-2 related infections and deaths were substantially higher, pressure on the healthcare system was more 
intense, while the confinement measures were considerably milder [10, 12].

We sought to evaluate and quantify IS care dynamics by analyzing the number of IS admissions and reperfusion interventions during the first two waves of the COVID-19 pandemic in Hungary by comparison to baseline and control periods.

\section{Methods}

Data source This study was based on the reimbursement database of the National Health Insurance Fund of Hungary (NHIFH). The NHIFH database prospectively registers all healthcare activities performed by healthcare providers supervised by the National Healthcare Service Center of Hungary (NHSC). Hungary has a single-payer healthcare financing system, and NHSC is the largest supporter of healthcare services in Hungary, serving 9.8 million people [37, 38]. In summary, our database encompasses all admissions for IS and all reperfusion interventions - intravenous thrombolysis (IVT) and endovascular therapy (EVT) - performed by healthcare providers supervised by NHSC from 2 January 2017 to 31 December 2020. All patient data were obtained in an anonymized form from the NHIFH.

We used the ICD-10 (10th version of the International Statistical Classification of Diseases and Related Health) I63, I64, and I66 codes to evaluate the number of IS admissions from the reimbursement database of NHIFH. A recent study showed that the cerebrovascular ICD-10 codes submitted for reimbursement purposes in Hungary could be used reliably for stroke epidemiological studies [39]. Since some institutes use the ICD-10 I66 code instead of the I63 code, we used this code in addition to I63 and I64 codes to evaluate the number of IS admissions. However, this method could result in an overestimation of IS incidence with an $8 \%$ maximal value, based on NHSC calculation [40]. Some authors suggest using not only the main discharge diagnosis but diagnoses in all five positions (i.e., main diagnosis for admission; basic disease; accompanying disorder; complication; cause of death) to select IS patients in an administrative database with maximal sensitivity $[39,41]$. We computed the number of IS admissions as the number of cases where ICD I63 or I64 or I66 codes presented in any of these five discharge diagnosis positions. With this approach, in contrast to stroke mimics (conditions not resulting from cerebral ischemia that present with neurological symptoms indistinguishable from a stroke), the following group of patients could be included in the cohort: acute ISs (patients admitted with acute onset neurological symptoms caused by cerebral ischemia), non-acute ISs (patients formerly treated with acute IS admitted for follow-up investigations), in-hospital ISs (patients admitted for non-stroke reasons but had an IS while hospitalized), IS chameleons (patients presented with clinical symptoms suggestive of another condition, which represents IS), and incidental asymptomatic cerebral infarcts (patients who were hospitalized for a condition other than stroke and had a brain imaging that showed an incidental asymptomatic brain infarct). Each patient counted only at the time of admission in a given week. However, early readmissions (discharged IS patients who were readmitted within a short time interval) were captured from the NHIFH database as separate IS cases, which could result in an overestimation of IS incidence.

To compute the number of IVTs and EVTs, we used the Orvosi Eljárások Nemzetközi Osztályozása (OENO) and the Homogén Betegségcsoportok (HBCs) codes, which are the Hungarian adaptations of International Classification of Procedures in Medicine codes, and Diagnosis Related Groups [42, 43].

IVT has clinical indications other than neurological ones, but acute IS is the only condition where IVT is performed in neurology. Thus, using the OENO code of IVT (OENO 06042), we first identified all IVT cases, irrespectively of the clinical indication. Then, we excluded the non-neurological cases by excluding cases where the HBCs showed other than a neurological indication. IVT cases where HBCs code was missing were included in the analysis, which could overestimate the number of IVTs, but do not alter our goal to detect changes in a process. With this approach, IVT performed in stroke mimics and inhospital ISs might be included in the cohort.

For EVT coding, most Hungarian neurointerventional facilities use (Type I coding) the OENO 33933 code (intracranial transarterial revascularization therapy). However, two neurointerventional institutions use the OENO 53958 code (intracranial percutaneous transluminal angioplasty) in part or in full instead of 
the 33933 code (Type II coding) [44]. Therefore we used both codes to obtain the best estimate of EVT numbers.

Our analysis of the Hungarian SARS-CoV-2 data was based on the Our World in Data GitHub database (sourced from the COVID-19 Data Repository by the Center for Systems Science and Engineering at Johns Hopkins University) [12].

Study periods The first SARS-CoV-2 infection occurred in Hungary on 4 March 2020 (10th week of 2020). On 11 March 2020 (11th week of 2020), the Hungarian government declared a state of emergency, which lasted until 18 June 2020 (25th week of 2020). With a repeated surge of COVID-19 cases, on 1 September 2020 (36th week of 2020), a COVID-19 entry control scheme was instituted, and on 4 November 2020 (45th week of 2020), a state of emergency went into effect again. Up to date, containment measures are still in place [10-12, 45].

The study periods are summarized in Fig. 1. Based on the epidemic's dynamic, we defined two COVIDperiods (Wave-1 and Wave-2) as representative of the first and the second waves of the COVID-19 epidemic in Hungary. Wave-1 period was defined as a 15-week long interval between the 11th and 25th weeks of

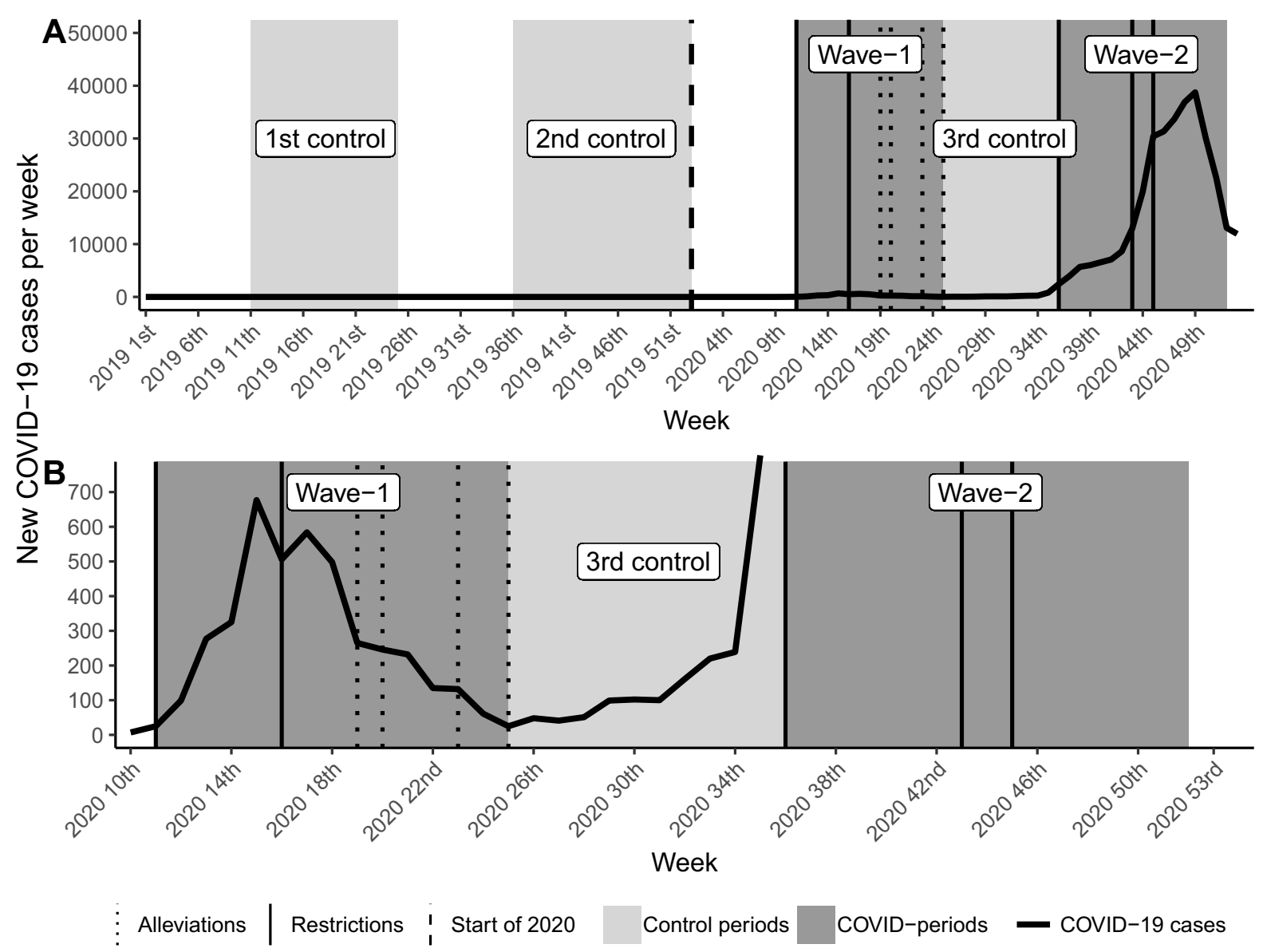

Fig. 1 Timeline and summary of the study periods. These graphs summarize the study periods and present them in a timeline, illustrating their temporal relationship to the COVID19 epidemic waves in Hungary. Dates of the most important restrictive and alleviative health emergency operative measures are also marked in the timelines. (a) illustrates both COVID-19 and control periods, while (b) focuses on the COVID-periods.
Wave-1 period: 11 th-25th weeks of 2020. Wave-2 period: 36th-52nd weeks of 2020. 1st control period: 11st-25th weeks of 2019. 2nd control period: 36th-52nd week of 2019. 3rd control period: 26th-35th weeks of 2020. COVID-19, coronavirus disease 2019; COVID-periods, periods of coronavirus disease 2019 
2020. Wave- 2 period was defined as a 17 -week long period between the 36th and 52nd weeks of 2020 . The 10-week long interval between the Wave-1 and Wave-2 period designated an epidemic interlude (3rd control period, 26th-35th weeks of 2020). Data of the COVID-periods were compared to their respective periods of 2019 (1st control period: 11th-25th weeks of 2019; 2nd control period: 36th-52nd week of 2019) and with the epidemic interlude. The comprehensive interval of the 11th-53rd weeks of 2020 , which extends from the start of the Wave- 1 period to the end of 2020, was used in the analyses to study the relationship between the number of COVID-19 cases and the investigated variables. Data from the 1 st week of 2017 to the 10th week of 2020 were defined as a baseline period for trend analysis.

Dates of the most important restrictive and alleviative health emergency operative measures were marked and used during the visual-statistical analyses (Fig. 1, 3,4, 5): 11th week of 2020, order of complete restriction of elective health care; 16th week of 2020, order to make $50-60 \%$ of beds free to COVID-care; 19th, 20th, 23rd, 25th weeks of 2020, four-step alleviation of restrictive health measures; 36th week, order to make $20 \%$ of beds free to COVID-care; $43 \mathrm{rd}$ week of 2020, orders to significantly expand the COVIDdesignated hospitals' number and make $20-30 \%$ of beds free to COVID-care; 45th week of 2020, orders to make $40 \%$ of beds free to COVID-care, to designate almost every hospital for COVID-care, and to partially restrict elective health care [12, 46-54].

Statistical analysis Statistical analysis was conducted on all characteristics (IS admissions, IVTs, EVTs) both separately and together. The smallest timeframe considered was weekly patient numbers due to the nature of the data.

We analyzed the COVID-19 epidemic waves' effect on the patient numbers with different tools: means, medians, trends, relative rates, and linear regression. The mean and median differences were tested with $t$ test and Wilcoxon-Mann-Whitney test, respectively. Differences between the COVID-periods and their respective controls were compared with the paired version of the tests. However, the COVIDperiods and the epidemic interlude were compared with non-paired tests due to differing lengths. Since similar findings were apparent using both means and medians, median-based data are presented as an online supplementary material (Table $\mathrm{S} 1$ ).

Trends and unexpected changes in patient numbers were analyzed using control charts, which are simple visual-statistical tools for detecting changes in a process and are widely used in outbreak analysis [5558]. The basic idea was to analyze a baseline timeframe (1st week of 2017-10th week of 2020) where it can be assumed that everything is in order and set up definitions for normal behavior. All data were linearly de-trended and standardized; thus we obtained z-scores. The potential effect of heteroscedasticity and seasonality was considered. However, we ultimately decided not to transform the data further due to two reasons: one was not to "over standardize" the data (i.e., categorize possibly extreme behavior during baseline as normal). The second was that these effects could be easily detected and taken into account visually. The z-cores were put on control charts, and the 2 and 3 standard deviation (SD) control limits were set. Changes in z-scores were then determined using Western Electric rules [56]. We also conducted statistical testing on the z-scores because compared to the raw numbers' means and medians; z-scores consider the trends based on the whole study period.

The rate of IVTs or EVTs relative to the number of IS admissions was also analyzed using control charts. These control charts used the same methodology as described above, but the de-trended and standardized IVT or EVT numbers were first divided by the number of IS admissions to get the relative number of patients.

Linear regression was used to analyze the relationship between the new or cumulative COVID-19 cases per week in Hungary and the weekly number of IS admissions, IVTs, or EVTs. The linear regression took the number of COVID-19 cases per week as the explanatory variable and the weekly IS admission, IVT, or EVT numbers as the outcome one.

While statistical tests did not use the incomplete last week of 2020 (data only for the first 4 days of the week were available), it was included in linear regression analysis and control charts to make the analysis and visual assessment as complete as possible. In this regard, when the characteristics were analyzed by themselves, the last patient number was multiplied by $7 / 4$ to boost it to a whole week level, but when the IVT and EVT numbers were divided by the number 
of IS admissions, the ratio was left because both data were equally incomplete; thus their ratio is valid.

Due to the different OENO coding practices for EVT, a correction had to be implemented to obtain the best estimate of patient numbers. This correction was based on the Type I coding centers by dividing the number of 53958 codes by the sum of the number of 33933 and 53958 codes, taking into account the whole study period. This gave an estimate of the true ratio of the 53958 codes, which was used to adjust the number of procedures in the Type II coding centers by multiplication. In the end, we added these adjusted 53958 numbers to the 33933 numbers.

$\mathrm{R}$ version 4.0.3 was used for data analysis with packages forecast, rgdal, ggplot2, ggpubr, gridExtra, flextable, and tableone.

Ethics This study was approved by the Institutional Review Boards/Institutional Ethics Committee of the National Institute of Clinical Neurosciences (predecessor institution of the National Mental, Neurological and Neurosurgical Institute; approval number: IKEB 2/2021) and by the Scientific and Research Ethics Committee of the Health Sciences Council of Hungary (ETT-TUKEB, approval number: IV/6781/2021/EKU). Written informed consent was waived due to the non-interventional, anonymized, and retrospective character of the investigation.

\section{Results}

In the Wave-1 period, compared to the 1 st control interval, we observed a significant decrease in the weekly IS admissions' mean and median. In the control chart, during the Wave-1 period, a marked negative deviation from the trend could be observed: values below the -2 SD control limit indicate alterations, and even if we consider the effect of multiple testing and use the -3 SD control limit, the disruption in the trend is clearly visible. Paired $t$ tests on IS admission z-scores also demonstrated a significant decline (Table 1, Figs. 2, 3, Table S1).

While the Wave- 1 period did not alter the mean and median of weekly EVT numbers considerably, the weekly IVT numbers' mean and median values reduced significantly in the Wave-1 period, compared to the 1st control interval (Table 1, Fig. 2, Table S1). Nevertheless, the de-trended and standardized weekly number of IVTs and EVTs showed a significant decrease in the Wave-1 period, representing a remarkable decline from the trend. In the control charts, the Wave-1 period's effect on the weekly EVT numbers was milder but detectable and significant: several consecutive observations were below the centerline, there was a case of 2-out-of-3 consecutive weeks below the -2 SD control limit, and the results of the difference tests on z-scores were also significant (Table 1, Fig. 4, Table S1). The trend analysis of the ratio of IVTs or EVTs and IS admissions showed a significant increase during the Wave-1 interval (Table 1, Fig. 5, Table S1). It implies that even though both the detrended and standardized weekly number of IVTs, EVTs, and IS admissions reduced in the Wave-1 period, the decrease of IS admissions was disproportionally greater.

Compared to the Wave-1 period, in the 3rd control period, the weekly number of IS admissions showed a clearly detectable increase in the raw numbers and the de-trended and standardized data (Table 1, Fig. 3, Table S1). In contrast, compared to the Wave-1 period, the weekly number of IVTs and EVTs did not change significantly in the epidemic interlude, neither in the raw data nor in the de-trended and standardized data. Simultaneously, the ratio of IVTs or EVTs and IS admissions returned to the baseline levels. (Table 1, Fig. 4, 5, Table S1).

In the Wave- 2 period, compared to the 2 nd control interval, the weekly IS admissions' mean and median values significantly decreased, but the mean and median of weekly IVTs and EVTs did not show a remarkable change (Table 1, Fig. 2, Table S1). However, the de-trended and standardized data analysis demonstrated a significant drop from the trend of IS admissions, IVTs, and EVTs. In the control charts, during the Wave-2 period, the ratio of IVTs or EVTs and IS admissions significantly increased, reaching even more extreme values (values beyond the $10 \mathrm{SD}$ limit) than in the Wave-1 interval (Table 1, Figs. 3, 4, 5, Table S1).

Comparing the raw numbers and z-scores of IS admissions and reperfusion interventions from the Wave-2 period with the 3 rd control period, we found similar results as compared with the 2nd control period, with two exceptions: compared to the epidemic interlude, not only the z-scores of EVT reduced significantly in the Wave- 2 period, but also the mean and median of raw numbers. Although the ratio of 


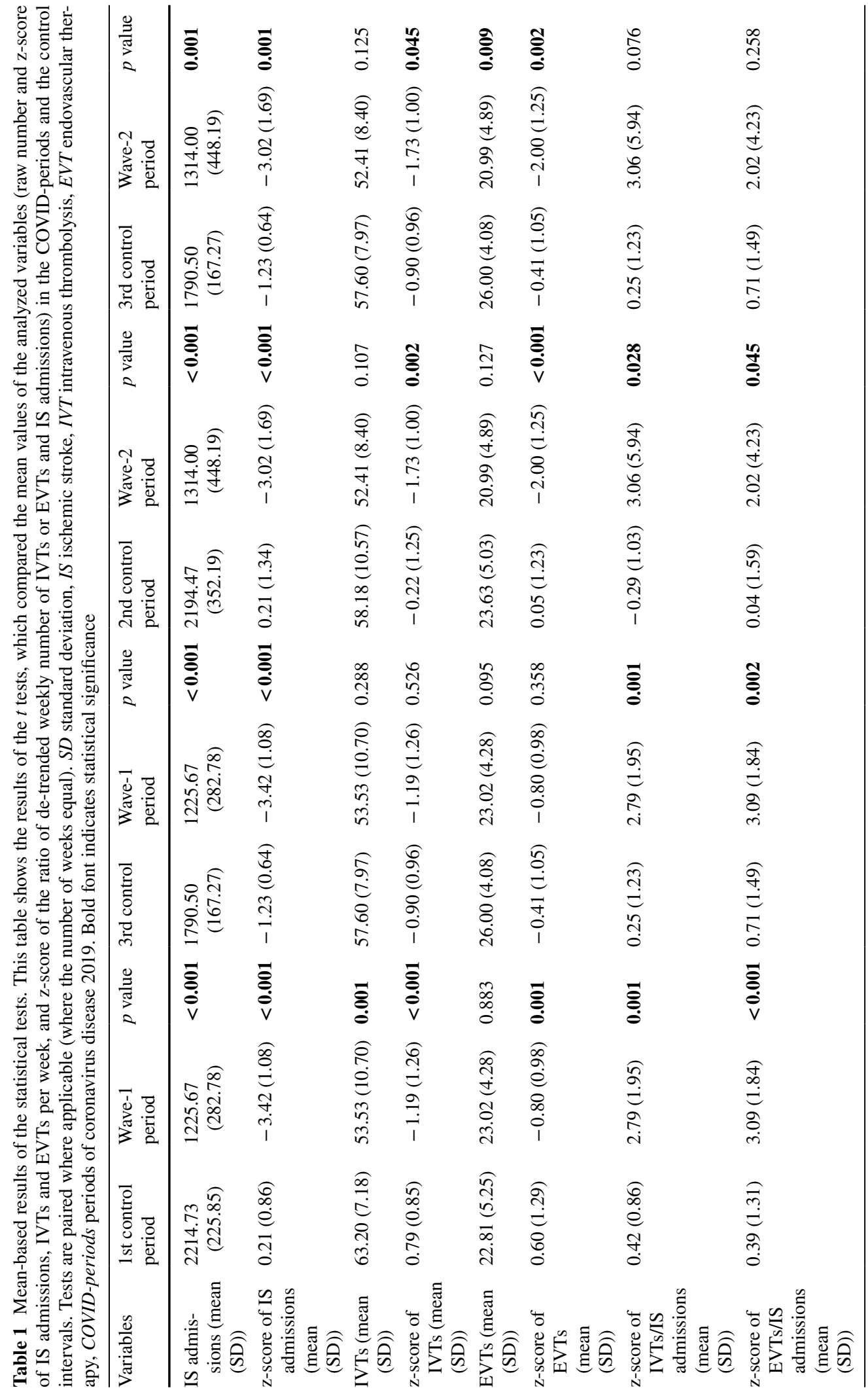




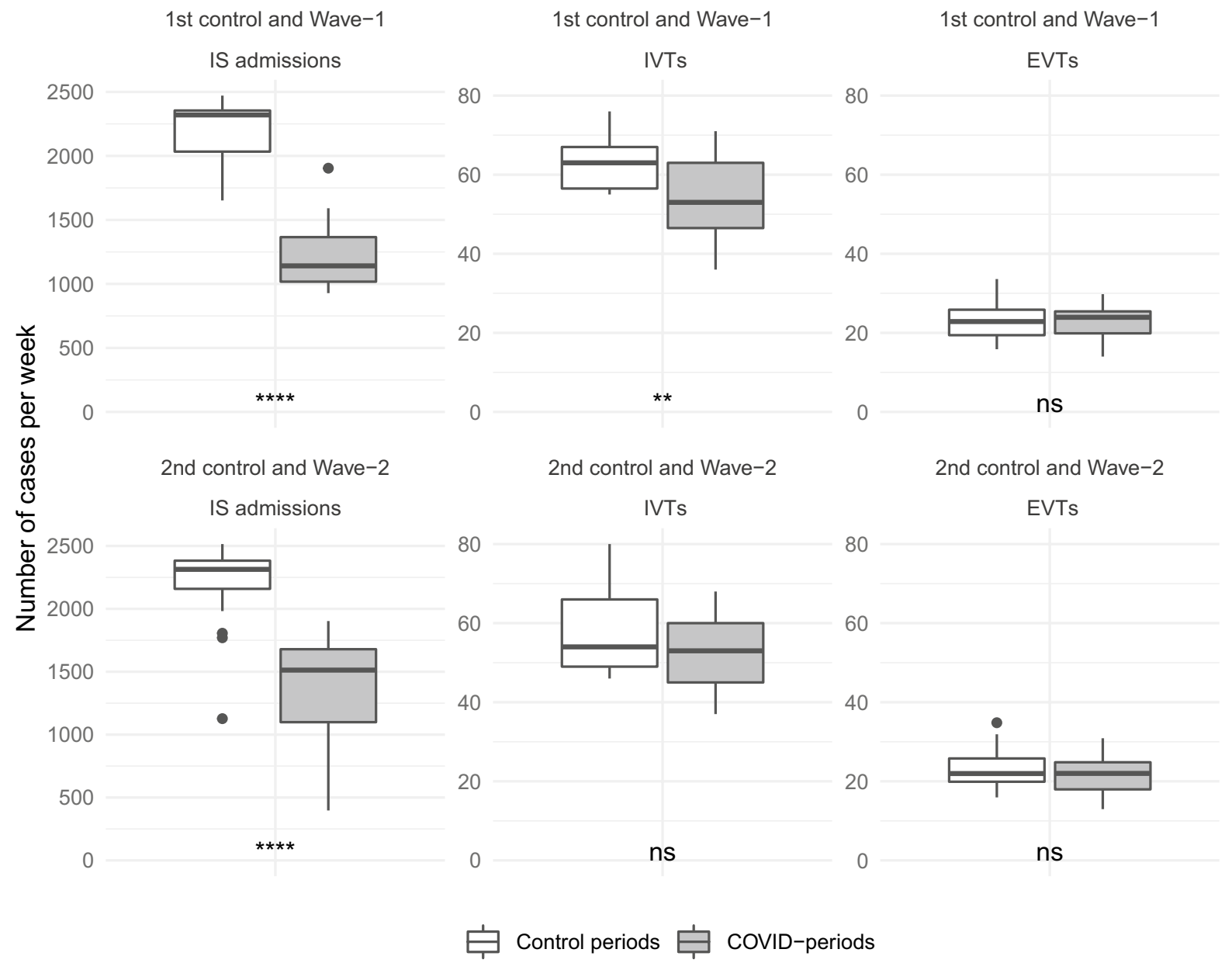

Fig. 2 Changes in the raw weekly number of IS admissions and reperfusion interventions during the COVID-periods. This figure shows the raw weekly number of IS admissions, IVTs, and EVTs in the COVID-periods and their respective controls using standard box plots. $p$ values of the paired Wilcoxon-Man-Whitney tests, which compare the COVID-peri-

IVTs or EVTs and IS admissions showed an extreme increase in the control charts, the mean and median of $\mathrm{z}$-scores did not alter significantly. The cause of this apparent contradiction is that the mean and median of $z$-scores use the whole length of the Wave- 2 period, but the analyzed ratios' $\mathrm{z}$-scores started to increase significantly only at the 43rd week of 2020 (Table 1 , Figs. 3, 4, 5, Table S1).

General analysis of the control charts In the IS admissions' control chart, the weekly number of IS admissions shows mild seasonality, guided mainly by vacations and national holidays. These changes ods to their respective controls, are also presented. full dots: Tukey-defined outliers; $p$ value: ns (not significant) $p>0.05$, $* * p<0.01, * * * * p<0.0001$; IS, ischemic stroke; IVT, intravenous thrombolysis; EVT, endovascular therapy; COVID-periods, periods of coronavirus disease 2019

may have inflated the variance in the baseline period (Fig. 3). In the control charts of reperfusion interventions, the baseline periods do not show any striking artifacts, only a mild increase in the variance can be seen. Occasional random extremes ("false alarms") occurred as expected (Fig. 4).

The winter holiday season (generally the $51 \mathrm{st}-1$ st weeks of a calendar year) tends to bring the weekly number of IS admissions extremely low (below a distance of $-3 \mathrm{SD}$ ), while the weekly IVT and EVT numbers do not alter remarkably. Thus concurrently, the ratio of IVTs or EVTs and IS admissions shows a significant (above a distance of 2 or $3 \mathrm{SD}$ ) increase 


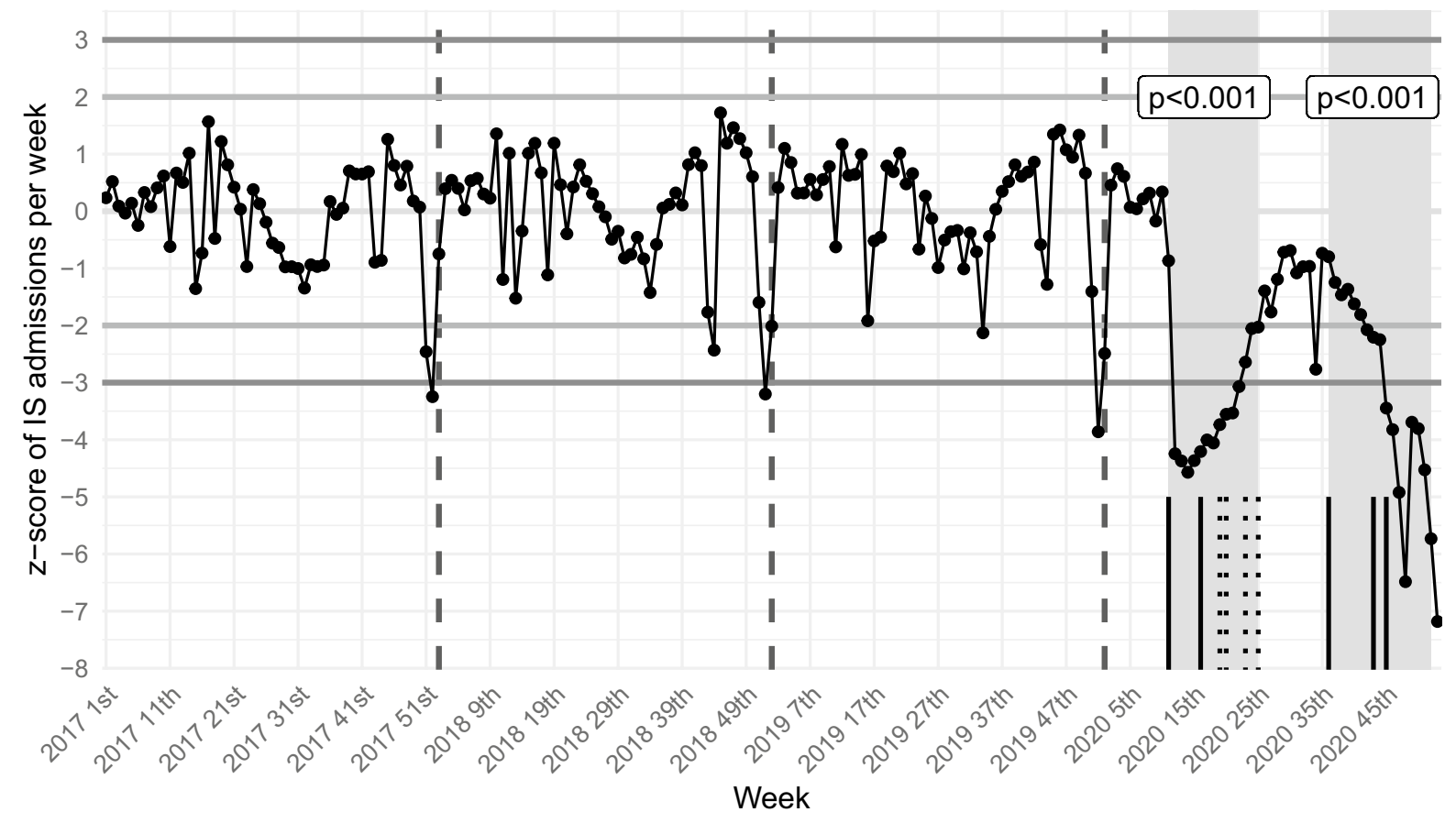

Baseline mean -2 sd. limit -3 sd. limit

\begin{tabular}{l|l:l} 
Alleviations & Restrictions & Start of year
\end{tabular}

COVID-periods

Fig. 3 Control chart of IS admissions. This graph visualizes the trend and changes using the de-trended and standardized weekly number of IS admissions during the whole study period. $p$ values of the paired $t$ tests, which compare the COVID-periods to their respective controls, are also presented.

(Figs. 3, 4, 5). The summer holiday season (generally the 24th-35th weeks of a calendar year) has a similar but longer-lasting and less potent effect on the weekly number of IS admissions, IVTs, and EVTs (Figs. 3, $4,5)$.

Linear regression analysis The weekly number of IS admissions, IVTs, and EVTs was compared with the new or cumulative SARS-CoV-2 infections' weekly number in Hungary during the comprehensive interval of the 11th-53rd weeks of 2020. The weekly number of IS admissions and EVTs significantly decreased with the increase of the new or cumulative COVID-19 cases per week (negative linear correlation), while the number of IVTs did not show a significant linear correlation with the number of SARSCoV-2 infections (Fig. 6). The relationship between variables may not be linear in several cases, but we did not investigate this angle any further as this
Dates of the most important restrictive and alleviative health emergency operative measures are marked in the timeline. sd, standard deviation; COVID-periods, periods of coronavirus disease 2019; IS, ischemic stroke

sub-analysis was mainly exploratory and just a complementary tool.

\section{Discussion}

Our study revealed that the mean and median values of weekly IS admissions and reperfusion interventions showed a decrease only in some measure during the two epidemic waves of COVID-19 in Hungary. However, the control charts demonstrated that these values reflect a significant disruption in the trends and decline in the number of IS admissions, IVTs, and EVTs. It is also notable that results regarding IS admissions were similar if we computed the number of IS admissions as the number of cases where ICD I63 or I64 or I66 codes presented only as primary discharge diagnosis (i.e., main diagnosis for admission) 


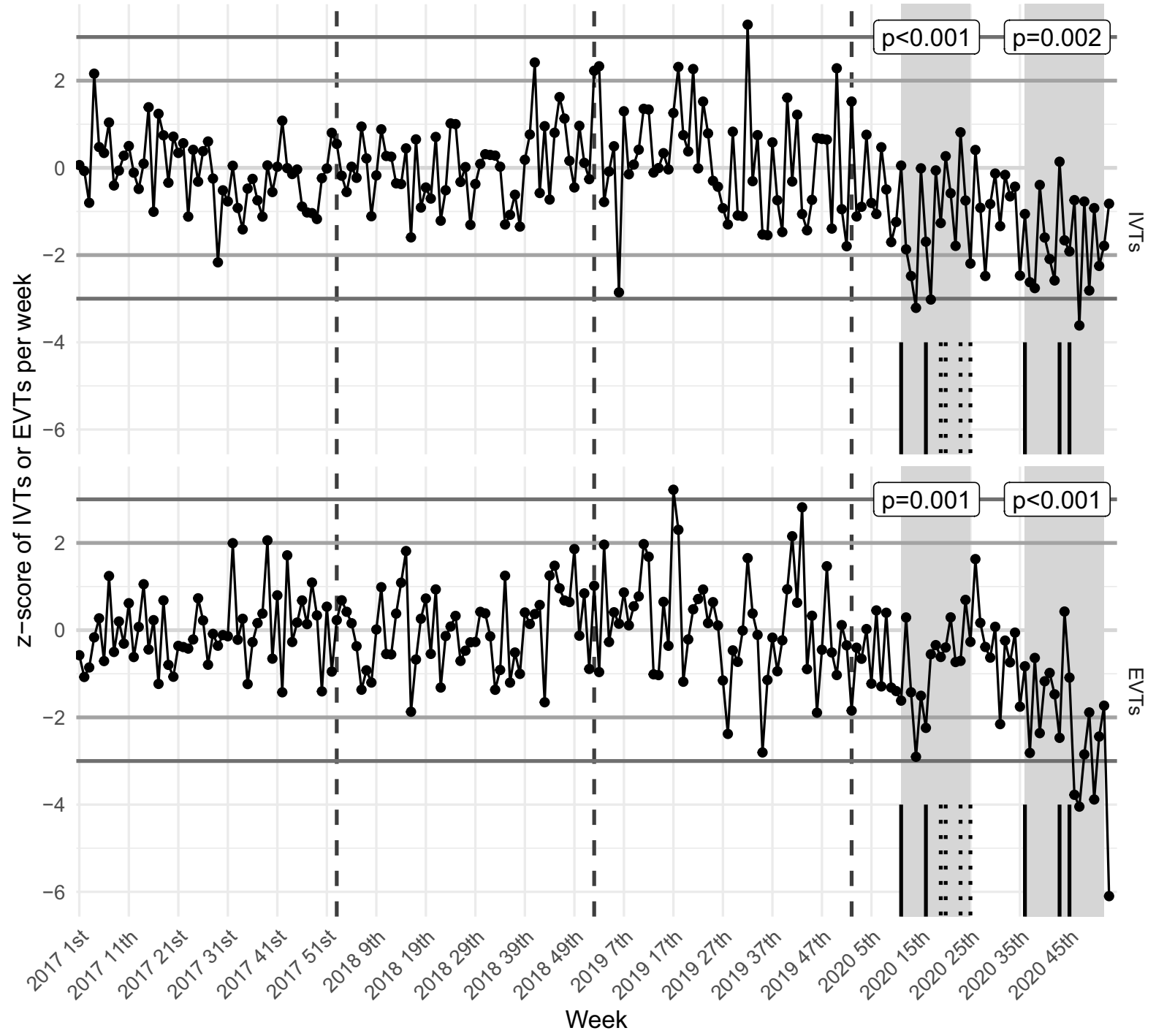

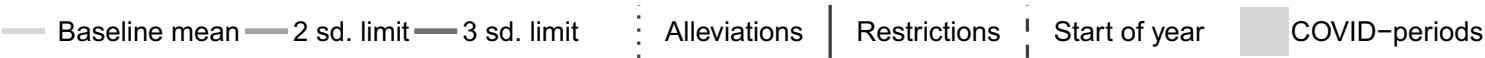

Fig. 4 Control chart of IVTs and EVTs. These charts visualize the trend and changes using the de-trended and standardized weekly number of IVTs and EVTs during the whole study period. $p$ values of the paired $t$ tests, which compare the COVID-periods to their respective controls, are also presented.

in the reimbursement database of NHIFH (data presented in the online supplementary Fig. S1-2).

Notwithstanding that a negative deviation from the trend could be observed both in IS admission numbers and in IVT and EVT numbers, the decline's dynamic and amplitude have differed for each variable. During the COVID-periods, the
Dates of the most important restrictive and alleviative health emergency operative measures are marked in the timeline. sd, standard deviation; COVID-periods, periods of coronavirus disease 2019; IVT, intravenous thrombolysis; EVT, endovascular therapy

number of IS admissions showed a high amplitude negative steep wave of decrease with a significant restoration in the epidemic interlude. Similarly, the EVT numbers decline also presented with a negative wave dynamic but with a smaller amplitude and without significant rearrangement in the epidemic interlude. In contrast, the IVT's decline from the 


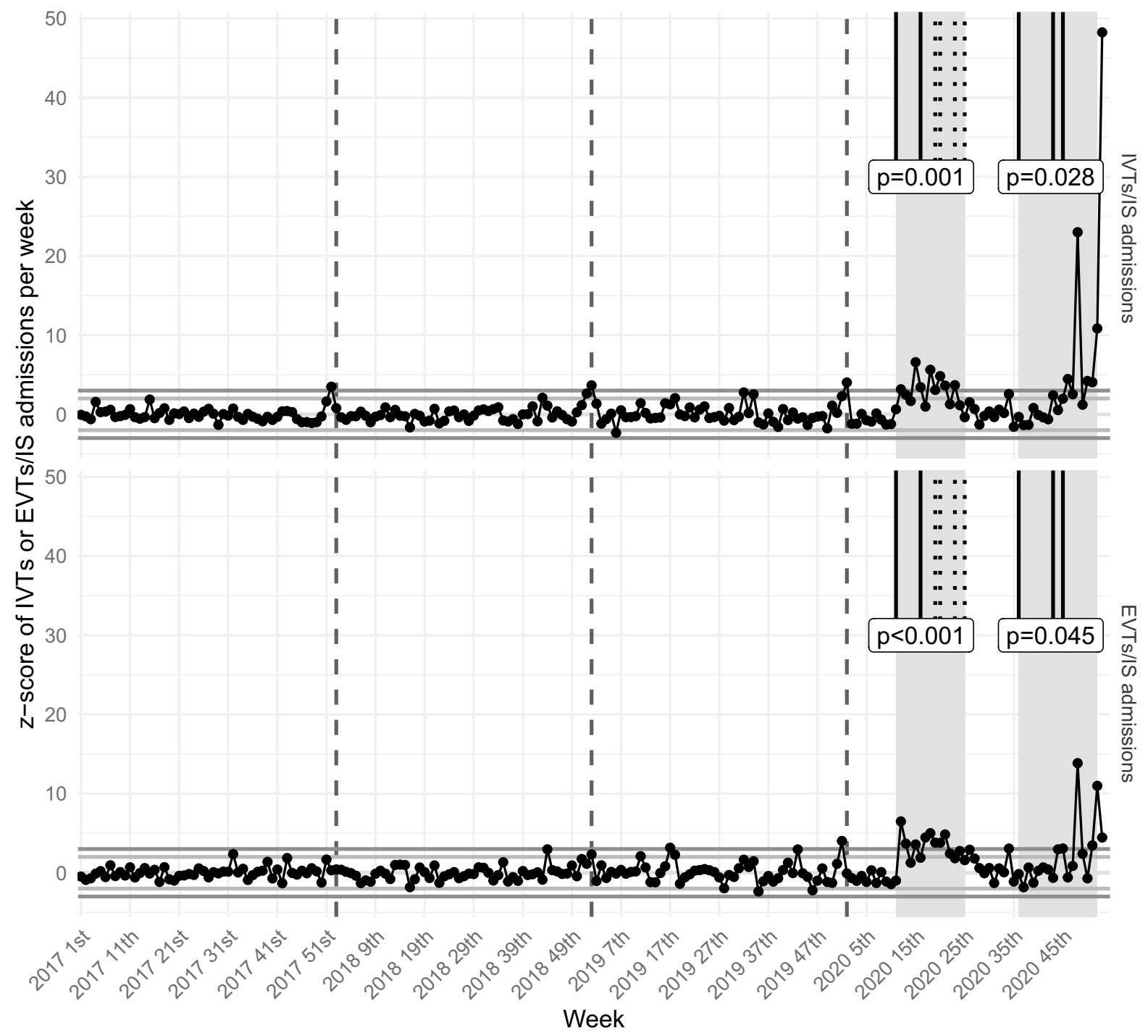

- Baseline mean -2 sd. limit -3 sd. limit

\begin{tabular}{l|lll} 
Alleviations & Restrictions i Start of year
\end{tabular}

COVID-periods

Fig. 5 Control chart of the ratio of IVTs or EVTs and IS admissions. These charts visualize the trend and changes using the de-trended and standardized weekly number of IVTs or EVTs relative to IS admissions during the whole study period. $p$ values of the paired $t$ tests, which compare the COVID-periods to their respective controls, are also presented. Dates of the

trend was rather stepwise (larger amplitude but less dynamic) during the first wave of the COVID-19 outbreak, and the extent of the deviation from the trend persisted through the epidemic interlude and the second epidemic wave. Additionally, our study most important restrictive and alleviative health emergency operative measures are marked in the timeline. sd, standard deviation; COVID-periods, periods of coronavirus disease 2019; IVT, intravenous thrombolysis; EVT, endovascular therapy; IS, ischemic stroke

demonstrated a significant negative correlation between the number of SARS-CoV-2 cases in Hungary and the number of IS admissions and EVTs. However, the number of IVTs changed regardless of the amplitude of the COVID-19 epidemic waves. 


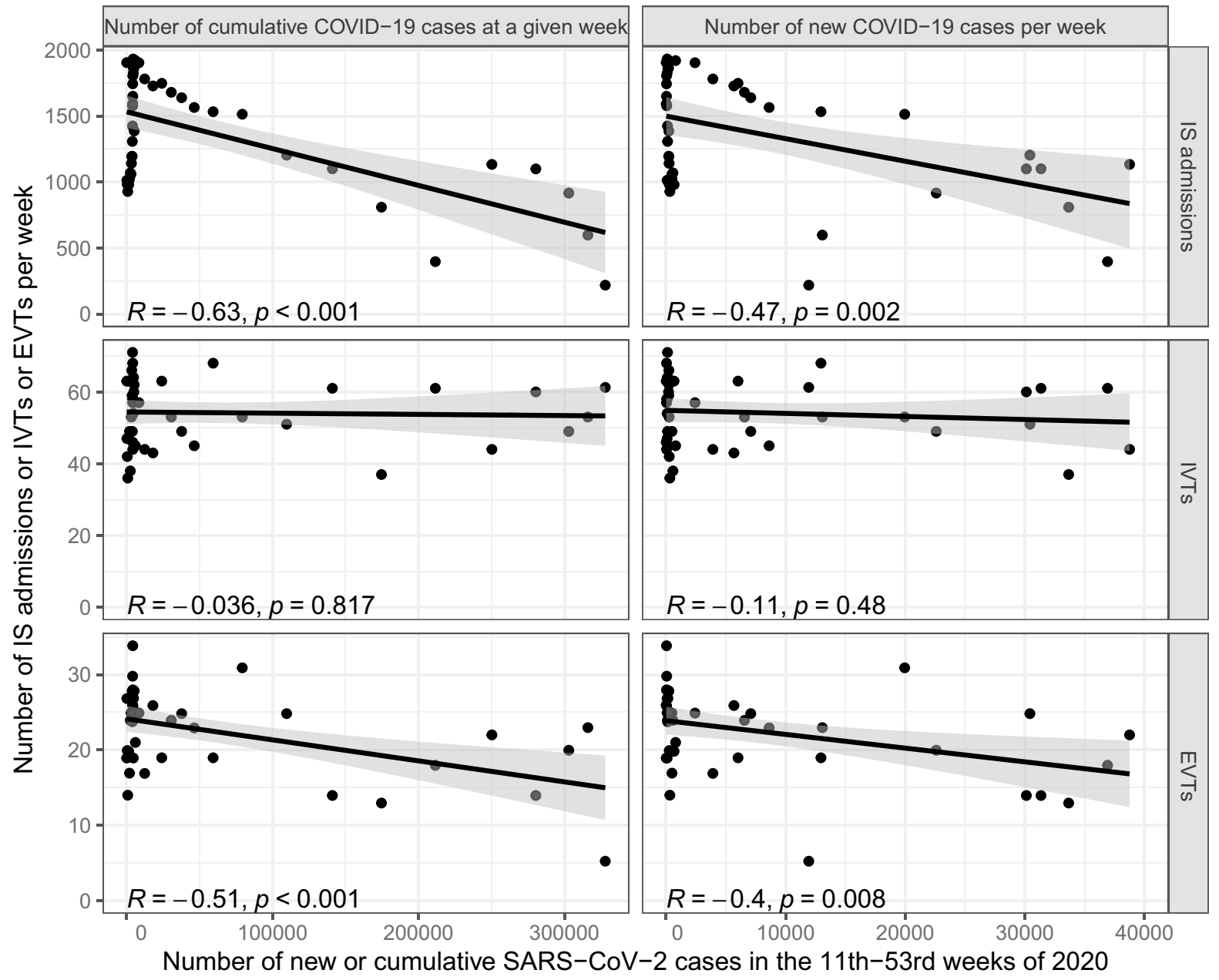

Fig. 6 Relationship between the weekly number of IS admissions, IVTs, and EVTs, and the new or cumulative SARSCoV-2 cases per week in Hungary. This figure visualizes the linear regression analysis results, which compared the weekly number of IS admissions, IVTs, and EVTs with the new or cumulative SARS-CoV-2 infections' weekly number in Hungary during the comprehensive interval of the 11th-53rd weeks of 2020, which extends from the start of the Wave-1

These results suggest that multiple different factors might play a role in disrupting the trends of the analyzed characteristics. Our study is unable to evaluate the causes, but several factors can be hypothesized. Some authors suggest that stroke incidence might decrease, but the European Stroke Organization and most authors agree that there is no well-grounded reason to assume that stroke incidence declined since the onset of the COVID-19 crisis [17, 23, 34, 59]. Furthermore, an overwhelmed emergency medical period (representative of the first COVID-19 epidemic wave in Hungary) to the end of 2020. R: Pearson's correlation coefficient; $p, p$ value of the correlation (same as the $p$ value of the linear regression); grey area, $95 \%$ confidence interval of the slope; IS, ischemic stroke; IVT, intravenous thrombolysis; EVT, endovascular therapy; SARS-CoV-2, severe acute respiratory syndrome coronavirus 2 ; COVID-19, coronavirus disease 2019

system and broken chain of stroke, prehospital and institutional epidemiological precautionary measures, stringent adherence to revascularization therapies' guidelines, social distancing, fear of acquiring the SARS-CoV-2 infection, and other changes in the social behavior also could be hypothesized [14, 16, $18,20,23,24,28], 31$, [31, 33, 34, 60-62]. We speculate that the health emergency operative measures as a $20-60 \%$ reduction in the number of available hospital beds to ensure the care of COVID-19 patients; a 
complete or partial restriction of elective health care could also play a role [10, 46, 47, 49-53].

During the two epidemic waves, the number of IS admissions decreased to a disproportionally larger extent than the number of reperfusion interventions. We hypothesize that the health emergency operative measures could be one of the causes because the dynamic of the disproportionally greater decrease of IS admissions seems to be mostly concurrent with the health emergency operative measures. During the Wave-1 period, the peak of the disproportionally greater reduction of IS admissions overlaps when $50-60 \%$ of beds had to be reserved for COVID-19 patients, and the gradual termination of this phenomenon co-occur with the four-step alleviation of restrictive measures. At the Wave-2 period, the IS admission numbers started to decrease to a disproportionally larger extent when the COVID-designated hospitals' number was expanded, and $20-40 \%$ of beds had to be reserved for COVID-19 patients. It could also be presumed the COVID-19 itself or the lifestyle altered by confinement measures could change the proportion of IS patients eligible for reperfusion therapies. Besides, changes in patients' social behavior (non-disabling IS cases, where reperfusion interventions would not have been indicated, could stay at home because of the fear of getting infected) could also contribute. Since stroke mimics are usually characterized by mild neurological symptoms, similarly to non-disabled IS cases, their reduced presentation, led by the fear of getting infected, might also be presumed in the COVID-periods [63]. However, while it could contribute to the decrease of IVTs, it cannot explain the decline of IS admissions because stroke mimics are not included in our cohort of IS admissions.

In the COVID-periods, a numerical pattern very similar to the winter and summer holiday seasons could be observed (an increase in the ratio of IVTs or EVTs and IS admissions), which might indirectly support both the behavioral and the healthy policy hypothesis. One might hypothesize that patients may not seek medical attention for acute neurological symptoms during winter and summer holidays unless they perceive that the symptoms are so severe (potentially IVT and EVT candidate cases) that it allows them no other choice. This theory could explain the increase in the ratio of reperfusion interventions and IS admissions during the winter and summer holiday seasons. During the epidemic waves, patients might have a very similar attitude, which might be motivated by the fear of getting infected, rather than not wanting to miss festivities. In the Wave-1 period, when patients might have little idea of what to expect from the COVID-19 epidemic, the fear might be high, which could cause an abrupt increase in the ratio of reperfusion interventions and IS admissions. While in the Wave-2 interval, when patients already had experiences of the epidemic's dangers, the fear might not reach Wave-1 level, despite SARS-CoV-2 cases being higher, until the COVID-19 case numbers and deaths reached an exceptionally high value. This theory could explain the later onset increase in the ratio of reperfusion interventions and IS admissions in the Wave-2 period. It is also presumable that non-acute IS admissions for follow-up investigations are less likely in the winter and summer holiday seasons, which might also explain the increase in the ratio of reperfusion interventions and IS admissions in these periods. In the Wave-1 interval, when governments and healthcare authorities might have little knowledge about the COVID-19 epidemic, strict restrictive measures were abruptly implemented. These restrictive measures rapidly made it impossible to admit elective, non-acute IS cases, which might also increase the ratio of reperfusion interventions and IS admissions in the Wave-1 interval. Presumably based on the experiences from the Wave-1, despite the higher COVID-19 case numbers, strict confinement measures and restriction of elective health care took place later in the Wave-2 period, which might also contribute to the later onset increase in the ratio of reperfusion interventions and IS admissions. Additionally, it can also be presumed that during the COVID-19 epidemic, patients were less likely to accept elective hospital admissions because of the fear of getting infected, even if it was allowed.

Behind the decline of EVT numbers, deceleration of the continuous growth of EVT numbers could also be hypothesized, which overlaps the time of the COVID-19 epidemic. However, it seems less likely since in our database annually maximum of $3 \%$ of patients with ICD-10 I63/I64/I66 primary discharge diagnosis codes were treated with EVT, while population-based studies from 2016 to 2017 estimated that $7-16 \%$ of all IS admissions are potentially eligible for EVT [64-66]. Moreover, evidence from recent years might increase further the proportion of acute IS patients eligible for EVT, making the theory of 
EVT's deceleration less probable [2-9]. Additionally, the inclusion of the first 10 weeks of 2020 in the baseline period also makes such a steep and prominent deviation from the EVT's baseline less like solely due to the deceleration of EVT's growth.

Our study's main limitations are our database's reimbursement purpose and our research's retrospective and observational nature and the different coding practices that had to be addressed. Furthermore, our study does not cover the entire second wave of the COVID-19 epidemic in Hungary.

In conclusion, our study demonstrated a significant disruption in IS care during the COVID-19 epidemic in Hungary. In the negative impact of the COVID-19 epidemic on IS care, multiple different factors might play a role. Furthermore, we revealed that the number of IS admissions decreased to a disproportionally larger extent than the number of reperfusion interventions during the first and second waves of the COVID-19 outbreak in Hungary, which could partially be explained by the effect of health emergency operative measures and changes in patients' social behavior. Further studies are needed to evaluate the causes of our observations. Our study highlights the importance of the IS care system's continuous surveillance and what we learned from these two COVID-19 waves we can use to preserve IS care in subsequent waves or future epidemics.

Acknowledgements We would like to express our sincere thanks to our contributors - Éva Kerekesné Kretzer and Marianna Farkas, employees of the National Health Insurance Fund of Hungary - for their kind assistance in the data collection. We would like to express our gratitude to Erik M. Liotta, Ayush Batra and Calin I. Prodan for their valuable comments on the manuscript. Dániel Bereczki is associated with the IRENE COST program of the European Union on quality assurance in stroke care.

Author contribution Listed using CRediT (Contribution Roles Taxonomy) classification.

Péter Pál Böjti: conceptualization, data curation, formal analysis, investigation, methodology, project administration, writing - original draft. Géza Szilágyi: conceptualization, methodology, resources, supervision, writing — review and editing. Balázs Dobi: data curation, formal analysis, methodology, software, visualization, writing - original draft. Rita Stang: data curation, investigation, visualization. István Szikora: investigation, resources, supervision, writing review and editing. Balázs Kis: investigation, visualization. Ákos Kornfeld: investigation. Csaba Óváry: investigation, resources, supervision. Lóránd Erőss: resources, supervision.
Péter Banczerowski: resources, supervision. Wojciech Kuczyński: formal analysis, methodology. Dániel Bereczki: conceptualization, formal analysis, methodology, resources, supervision, validation, writing — review and editing.

Funding Open access funding provided by Semmelweis University.

Data availability The data of this study are available from the corresponding author upon reasonable request.

Code availability $\mathrm{R}$ version 4.0 .3 is a free software.

\section{Declarations}

Ethics approval This study was approved by the Institutional Review Board/ Institutional Ethics Committee of the National Institute of Clinical Neurosciences (predecessor institution of the National Mental, Neurological and Neurosurgical Institute; approval number: IKEB 2/2021) and by the Scientific and Research Ethics Committee of the Health Sciences Council of Hungary (ETT-TUKEB, approval number: IV/678-1/2021/ EKU).

Consent to participate Written informed consent was waived due to the non-interventional, anonymized, and retrospective character of the investigation.

Consent for publication The authors consent to the publication of the attached manuscript.

Conflict of interest The authors declare no competing interests.

Open Access This article is licensed under a Creative Commons Attribution 4.0 International License, which permits use, sharing, adaptation, distribution and reproduction in any medium or format, as long as you give appropriate credit to the original author(s) and the source, provide a link to the Creative Commons licence, and indicate if changes were made. The images or other third party material in this article are included in the article's Creative Commons licence, unless indicated otherwise in a credit line to the material. If material is not included in the article's Creative Commons licence and your intended use is not permitted by statutory regulation or exceeds the permitted use, you will need to obtain permission directly from the copyright holder. To view a copy of this licence, visit http://creativecommons.org/licenses/by/4.0/.

\section{References}

1. Donkor ES. Stroke in the 21(st) Century: a snapshot of the burden, epidemiology, and quality of life. Stroke Res Treat. 2018;2018:3238165. https://doi.org/10.1155/2018/ 3238165 . 
2. Rabinstein AA. Treatment of acute ischemic stroke. Continuum. 2017;23(1):62-81. https://doi.org/10.1212/con. 0000000000000420 .

3. Catanese L, Tarsia J, Fisher M. Acute ischemic stroke therapy overview. Circ Res. 2017;120(3):541-58. https:// doi.org/10.1161/circresaha.116.309278.

4. Turc G, Bhogal P, Fischer U, Khatri P, Lobotesis K, Mazighi M, et al. European Stroke Organisation (ESO) - European society for minimally invasive neurological therapy (ESMINT) guidelines on mechanical thrombectomy in acute ischaemic stroke endorsed by stroke alliance for Europe (SAFE). Eur Stroke J. 2019;4(1):6-12. https:// doi.org/10.1177/2396987319832140.

5. Berge E, Whiteley W, Audebert H, De Marchis GM, Fonseca AC, Padiglioni C, et al. European Stroke Organisation (ESO) guidelines on intravenous thrombolysis for acute ischaemic stroke. Eur Stroke J. 2021;6(1):I-LXII. https://doi.org/10.1177/2396987321989865

6. Nogueira RG, Jadhav AP, Haussen DC, Bonafe A, Budzik RF, Bhuva P, et al. Thrombectomy 6 to 24 hours after stroke with a mismatch between deficit and infarct. $\mathrm{N}$ Engl J Med. 2018;378(1):11-21. https://doi.org/10.1056/ NEJMoa1706442.

7. Albers GW, Marks MP, Kemp S, Christensen S, Tsai JP, Ortega-Gutierrez S, et al. Thrombectomy for stroke at 6 to 16 hours with selection by perfusion imaging. N Engl J Med. 2018;378(8):708-18. https://doi.org/10.1056/ NEJMoa1713973.

8. Ma H, Campbell BCV, Parsons MW, Churilov L, Levi $\mathrm{CR}$, Hsu C, et al. Thrombolysis guided by perfusion imaging up to 9 hours after onset of stroke. N Engl J Med. 2019;380(19):1795-803. https://doi.org/10.1056/NEJMo a1813046.

9. Thomalla G, Simonsen CZ, Boutitie F, Andersen G, Berthezene Y, Cheng B, et al. MRI-guided thrombolysis for stroke with unknown time of onset. N Engl J Med. 2018;379(7):611-22. https://doi.org/10.1056/NEJMo a1804355.

10. Miniszterelnöki Kabinetiroda, Magyarország Kormánya. [Prime Minister's Office, Government of Hungary]. Tájékoztató oldal a koronavírusról. [Informational website on coronavirus]. [Internet]. Budapest, Hungary: Miniszterelnöki Kabinetiroda, Magyarország Kormánya. [Prime Minister's Office, Government of Hungary]; 2020 [updated daily; cited 2021 June 8]. Available from: https:// koronavirus.gov.hu/. Hungarian.

11. World Health Organisation. WHO Coronavirus Disease (COVID-19) Dashboard. 2020 [updated daily; cited 2021 June 8]. World Health Organisation. Available from: https://covid19.who.int/

12. Roser M, Ritchie H, Ortiz-Ospina E, Hasell J. Coronavirus pandemic (COVID-19). 2020 [updated daily; cited 2021 June 8]. Our world in data. Available from: https:// ourworldindata.org/coronavirus

13. Institute for Health Metrics and Evaluation. Estimation of total mortality due to COVID-19. 2021. [Internet]. Seattle, United States of America: Institute for Health Metrics and Evaluation; 2021 May 13 [cited 2021 June 8]. Available from: http://www.healthdata.org/special-analysis/estim ation-excess-mortality-due-covid-19-and-scalars-repor ted-covid-19-deaths
14. Agarwal S, Scher E, Rossan-Raghunath N, Marolia D, Butnar M, Torres J, et al. Acute stroke care in a New York City comprehensive stroke center during the COVID-19 pandemic. J Stroke Cerebrovasc Dis. 2020;29(9): 105068. https://doi.org/10.1016/j.jstrokecerebrovasdis. 2020. 105068.

15. Baracchini C, Pieroni A, Viaro F, Cianci V, Cattelan AM, Tiberio I, et al. Acute stroke management pathway during coronavirus-19 pandemic. Neurol Sci. 2020;41(5):10035. https://doi.org/10.1007/s10072-020-04375-9.

16. Bersano A, Kraemer M, Touzé E, Weber R, Alamowitch $\mathrm{S}$, Sibon I, et al. Stroke care during the COVID-19 pandemic: experience from three large European countries. Eur J Neurol. 2020;27(9):1794-800. https://doi.org/10. 1111/ene.14375.

17. Böjti PP, Stang R, Gunda B, Sipos I, Bereczki D. A járulékos egészségügyi veszteségek retrospektív, egycentrumos felmérése. [Effects of COVID-19 pandemic on acute ischemic stroke care. A single-centre retrospective analysis of medical collateral damage]. Orv Hetil. 2020;161(34):1395-9. https://doi.org/10.1556/650.2020. 31936. Hungarian.

18. Bres Bullrich M, Fridman S, Mandzia JL, Mai LM, Khaw A, Vargas Gonzalez JC, et al. COVID-19: stroke admissions, emergency department visits, and prevention clinic referrals. Can J Neurol Sci. 2020;47(5):693-6. https://doi. org/10.1017/cjn.2020.101.

19. de Havenon A, Ney J, Callaghan B, Delic A, Hohmann S, Shippey E, et al. A rapid decrease in stroke, acute coronary syndrome, and corresponding interventions at 65 United States hospitals following emergence of COVID19. Version: 1. medRxiv [Preprint]. [posted 2020 May 7; cited 2021 June 8]. Available from: https://doi.org/10. 1101/2020.05.07.20083386

20. Esenwa C, Parides MK, Labovitz DL. The effect of COVID-19 on stroke hospitalizations in New York City. J Stroke Cerebrovasc Dis. 2020;29(10): 105114. https://doi. org/10.1016/j.jstrokecerebrovasdis.2020.105114.

21. Feral-Pierssens AL, Claret PG, Chouihed T. Collateral damage of the COVID-19 outbreak: expression of concern. Eur J Emerg Med. 2020;27(4):233-4. https://doi.org/ 10.1097/mej.0000000000000717.

22. Frisullo G, Brunetti V, Di Iorio R, Broccolini A, Caliandro P, Monforte M, et al. Effect of lockdown on the management of ischemic stroke: an Italian experience from a COVID hospital. Neurol Sci. 2020;41(9):2309-13. https:// doi.org/10.1007/s10072-020-04545-9.

23. Hoyer C, Ebert A, Huttner HB, Puetz V, Kallmünzer B, Barlinn K, et al. Acute stroke in times of the COVID-19 pandemic: a multicenter study. Stroke. 2020;51(7):22247. https://doi.org/10.1161/strokeaha.120.030395.

24. Montaner J, Barragán-Prieto A, Pérez-Sánchez S, Escudero-Martínez I, Moniche F, Sánchez-Miura JA, et al. Break in the stroke chain of survival due to COVID-19. Stroke. 2020;51(8):2307-14. https://doi.org/10.1161/strok eaha.120.030106.

25. Morelli N, Rota E, Terracciano C, Immovilli P, Spallazzi M, Colombi D, et al. The Baffling case of ischemic stroke disappearance from the casualty department in the COVID-19 Era. Eur Neurol. 2020;83(2):213-5. https:// doi.org/10.1159/000507666. 
26. Nguyen-Huynh MN, Tang XN, Vinson DR, Flint AC, Alexander JG, Meighan M, et al. Acute stroke presentation, care, and outcomes in community hospitals in Northern California during the COVID-19 pandemic. Stroke. 2020;51(10):2918-24. https://doi.org/10.1161/strokeaha. 120.031099 .

27. Pop R, Quenardelle V, Hasiu A, Mihoc D, Sellal F, Dugay $\mathrm{MH}$, et al. Impact of the COVID-19 outbreak on acute stroke pathways - insights from the Alsace region in France. Eur J Neurol. 2020;27(9):1783-7. https://doi.org/ 10.1111/ene.14316.

28. Rudilosso S, Laredo C, Vera V, Vargas M, Renú A, Llull $\mathrm{L}$, et al. Acute stroke care is at risk in the era of COVID19: experience at a comprehensive stroke center in Barcelona. Stroke. 2020;51(7):1991-5. https://doi.org/10.1161/ strokeaha.120.030329.

29. Sarfo FS, Mensah NO, Opoku FA, Adusei-Mensah N, Ampofo M, Ovbiagele B. COVID-19 and stroke: experience in a Ghanaian healthcare system. J Neurol Sci. 2020;416: 117044. https://doi.org/10.1016/j.jns.2020. 117044.

30. Slowik A, Nowak R, Popiela T. Significant fall in stroke admissions in the Malopolska Voivodeship of Poland during the COVID-19 pandemic. Neurol Neurochir Pol. 2020;54(5):471-2. https://doi.org/10.5603/PJNNS.a2020. 0056.

31. Sweid A, Jabbour P, Tjoumakaris S. Letter to the editor: incidence of acute ischemic stroke and rate of mechanical thrombectomy during the COVID-19 pandemic in a large tertiary care telemedicine network. World Neurosurg. 2020;140:491-2. https://doi.org/10.1016/j.wneu.2020.06. 053.

32. Sylaja PN, Srivastava MVP, Shah S, Bhatia R, Khurana D, Sharma A, et al. The SARS-CoV-2/COVID-19 pandemic and challenges in stroke care in India. Ann N Y Acad Sci. 2020;1473(1):3-10. https://doi.org/10.1111/nyas.14379.

33. Tejada Meza H, Lambea Gil Á, Saldaña AS, MartínezZabaleta M, Juez PR, Martínez EL, et al. Impact of COVID-19 outbreak on ischemic stroke admissions and in-hospital mortality in North-West Spain. Int J Stroke. 2020;15(7):755-62. https://doi.org/10.1177/1747493020 938301.

34. Tejada Meza H, Lambea Gil A, Sancho Saldana A, Martinez-Zabaleta M, Garmendia Lopetegui E, Lopez-Cancio Martinez E, et al. Impact of COVID-19 outbreak in reperfusion therapies of acute ischaemic stroke in northwest Spain. Eur J Neurol. 2020;27(12):2491-8. https://doi.org/ 10.1111/ene.14467.

35. Teo KC, Leung WCY, Wong YK, Liu RKC, Chan AHY, Choi OMY, et al. Delays in stroke onset to hospital arrival time during COVID-19. Stroke. 2020;51(7):2228-31. https://doi.org/10.1161/strokeaha.120.030105.

36. Zhao J, Rudd A, Liu R. Challenges and potential solutions of stroke care during the coronavirus disease 2019 (COVID-19) outbreak. Stroke. 2020;51(5):1356-7. https://doi.org/10.1161/strokeaha.120.029701.

37. National Healthcare Service Center of Hungary. Better way of care. [Internet]. Budapest, Hungary: National Healthcare Service Center of Hungary; [date unknown] [cited 2021 June 8]. Available from: https://okfo.gov.hu/ hu/web/national-healthcare-services-center/main-page
38. National Health Insurance Fund of Hungary. Tasks of the National Health Insurance Fund of Hungary. [Internet]. Budapest, Hungary: National Healthcare Service Center of Hungary; [date unknown] [cited 2021 June 8]. Available from: http://www.neak.gov.hu/felso_menu/rolunk/ kozerdeku_adatok/tevekenysegre_mukodesre_vonatkozo_ adatok/a_szerv_feladata_alaptevekenysege_es_hatarkore/ en_a_szerv_alaptevekenyege_feladata_es_hatarkore

39. Ajtay A, Oberfrank F, Bereczki D. A kórházi adatlapok jelentéseinek alkalmazhatósága epidemiológiai elemzésekre az ischaemiás cerebrovascularis betegségek példája alapján. [Applicability of hospital reports submitted for reimbursement purposes for epidemiological studies based on the example of ischemic cerebrovascular diseases]. Orv Hetil. 2015;156(38):1540-6. https://doi.org/ 10.1556/650.2015.30258. Hungarian.

40. Állami Egészségügyi Ellátó Központ. [National Healthcare Service Center of Hungary]. A magyar egészségügyi rendszer teljesítményértékelési jelentése 2013-15. [Health system performance assessment 2013-15]. [Internet]. Budapest, Hungary: Állami Egészségügyi Ellátó Központ [National Health Insurance Fund of Hungary]; 2016 Dec [cited 2021 June 8] 813-4, 819 p. Available from: https:// mertek.aeek.hu/web/mertek-magyar-egeszsegugyi-rends zer-teljesitmenyertekelese/jelentes-2013-15. Hungarian.

41. Tirschwell DL, Longstreth WT Jr. Validating administrative data in stroke research. Stroke. 2002;33(10):2465-70. https://doi.org/10.1161/01.str.0000032240.28636.bd.

42. Nemzeti Egészségbiztosítási Alapkezelő [National Health Insurance Fund of Hungary]. Fekvőbeteg eljárástörzs. [Inpatient Procedure Codes]. [Data file]. Nemzeti Egészségbiztosítási Alapkezelő [National Health Insurance Fund of Hungary]: Budapest, Hungary; [date unknown] [updated 2020 Feb 2; cited 2021 June 8]. Available from: http://www.neak.gov.hu/data/cms1020362/MUT_2002. ZIP. Hungarian.

43. Nemzeti Egészségbiztosítási Alapkezelő [National Health Insurance Fund of Hungary]. HBCs 5.0 Szabálykönyv. [HBCs 5.0 Rulebook]. [Data file]. Budapest, Hungary; [date unknown] [updated 2020 Feb 1; cited 2021 June 8]. Available from: http://www.neak.gov.hu//data/ cms1025530/10_2012_NEFMI_fekvo_2020.02.01.docx. Hungarian.

44. Szikora I, Vajda Z, Lenzsér G, Tóth J, Lázár I, Németh $\mathrm{T}$ et al. Az akut stroke neurointervenciós kezelése a hazai trombektomiás központok tapasztalatában: sikerek és nehézségek, esetszámok és klinikai eredmények. [Neurointerventional treatment of acute stroke in the Hungarian thrombectomy centers: experiences, successes and difficulties, caseload, and clinical results]. [video on the Internet]. Presented online at: Magyar Neuroradiológiai Társaság Kongresszusa 2020 [2020 Congress of Hungarian Society of Neuroradiology]; 2020 Nov 14 [cited 2021 June 8]. Available from: https://mnrt.hu/2020strokecentr um/. Hungarian.

45. United States Embassy in Hungary . COVID-19 Information [Internet]. Budapest, Hungary: United States Embassy in Hungary; 2020 [updated daily; cited 2021 June 8]. Available from: https://hu.usembassy.gov/ covid-19/ 
46. Emberi Erőforrások Minisztériuma, Magyarország Kormánya. [Ministry of Human Resources of Hungary]. EMMI: Egyetlen beteget sem kell hazaküldeni a kórházakból. [EMMI: No patients need to be sent home from hospitals]. [Internet]. Budapest, Hungary: Miniszterelnöki Kabinetiroda, Magyarország Kormánya. [Prime Minister's Office, Government of Hungary]; 2020 Sept 10 [cited 2021 June 8]. Available from: https://koronavirus.gov.hu/cikkek/emmi-egyetlen-beteget-sem-kell-hazak uldeni-korhazakbol. Hungarian.

47. Emberi Erőforrások Minisztériuma, Magyarország Kormánya. [Ministry of Human Resources of Hungary]. Az egésészégügy fokozatos újraindításán van a hangsúly. [The focus is on the gradual restart of health care]. [Internet]. Budapest, Hungary: Miniszterelnöki Kabinetiroda, Magyarország Kormánya. [Prime Minister's Office, Government of Hungary]; 2020 May 15 [cited 2021 June 8]. Available from: https://koronavirus.gov.hu/cikkek/emmiaz-egeszsegugy-fokozatos-ujrainditasan-van-hangsuly. Hungarian.

48. Emberi Erőforrások Minisztériuma, Magyarország Kormánya. [Ministry of Human Resources of Hungary]. Tovább bővülnek az egészségügyi ellátások. [The range of the available healthcare services are widening]. [Internet]. Budapest, Hungary: Miniszterelnöki Kabinetiroda, Magyarország Kormánya. [Prime Minister's Office, Government of Hungary]; 2020 May 30 [cited 2021 June 8]. Available from: https://koronavirus.gov.hu/cikkek/tovabbbovulnek-az-egeszsegugyi-ellatasok. Hungarian.

49. Magyar Távirati Iroda. [Hungarian Telegraphic Office]. Hétfőtől újraindulhat az egészségügyi ellátás. [Health care may restart from Monday]. [Internet]. Budapest, Hungary: Miniszterelnöki Kabinetiroda, Magyarország Kormánya. [Prime Minister's Office, Government of Hungary]; 2020 Jun 12 [cited 2021 June 8]. Available from: https://koron avirus.gov.hu/cikkek/hetfotol-ujraindulhat-az-egeszsegug yi-ellatas. Hungarian.

50. Miniszterelnöki Kabinetiroda, Magyarország Kormánya. [Prime Minister's Office, Government of Hungary]. A kórházak országszerte felkészülnek a tömeges megbetegedésekre. [Hospitals across the country are preparing for mass illnesses]. [Internet]. Budapest, Hungary: Miniszterelnöki Kabinetiroda, Magyarország Kormánya. [Prime Minister's Office, Government of Hungary]; 2020 Apr 16 [cited 2021 June 8]. Available from: https://koronavirus. gov.hu/cikkek/korhazak-orszagszerte-felkeszulnek-tomeg es-megbetegedesekre. Hungarian.

51. Semmelweis Egyetem [Semmelweis University]. A klinikai központ tájékoztatója. [Information from the Clincal Center of Semmelweis University]. [Internet]. Budapest, Hungary: Semmelweis Egyetem [Semmelweis University]; 2020 Mar 16 [cited 2021 June 8]. Available from: https://semmelweis.hu/hirek/2020/03/16/a-klinikai-kozpo nt-tajekoztatoja/. Hungarian.

52. Emberi Erőforrások Minisztériuma, Magyarország Kormánya. [Ministry of Human Resources of Hungary]. Kásler Miklós bővítette a Covid-ellátásba bevont intézmények körét. [Miklós Kásler expanded the number of COVID-designated hospitals]. [Internet]. Budapest, Hungary: Miniszterelnöki Kabinetiroda, Magyarország Kormánya. [Prime Minister's Office, Government of
Hungary]; 2020 Oct 25 [cited 2021 June 8]. Available from: https://koronavirus.gov.hu/cikkek/kasler-miklosbovitette-covid-ellat asba-bevont-intezmenyek-koret. Hungarian.

53. Magyar Távirati Iroda. [Hungarian Telegraphic Office]. Kásler Miklós elrendelte a halasztható mútétek felfüggesztését keddtől. [Miklós Kásler orderd to suspend the elective procedures from thuesday]. [Internet]. Budapest, Hungary: Miniszterelnöki Kabinetiroda, Magyarország Kormánya. [Prime Minister's Office, Government of Hungary]; 2020 Nov 7 [cited 2021 June 8]. Available from: https://koronavirus.gov.hu/cikkek/kasler-mikloselrendelte-halaszthato-mutetek-felfuggeszteset-keddtol. Hungarian.

54. Emberi Erőforrások Minisztáriuma, Magyarország Kormánya. [Ministry of Human Resources of Hungary]. Az egészségügyi ellátás új rendje. [New orders in healthcare]. [Internet]. Budapest, Hungary: Emberi Erőforrások Minisztériuma, Magyarország Kormánya. [Ministry of Human Resources of Hungary]; 2020 Apr 30 [cited 2021 June 8]. Available from: https://www.kamara.fogor $\operatorname{vos} . \mathrm{hu} /$ ? module $=$ news $\&$ action $=$ getfile $\&$ fid $=254650$. Hungarian.

55. Farrington CP, Andrews NJ, Beale AD, Catchpole MA. A statistical algorithm for the early detection of outbreaks of infectious disease. J R Stat Soc A Stat. 1996;159(3):54763. https://doi.org/10.2307/2983331.

56. Montgomery DC. Introduction to statistical quality control. 6th ed. John Wiley \& Sons Association; 2009. p. 179-213.

57. Nielsen J, Vestergaard LS, Richter L, Schmid D, Bustos $\mathrm{N}$, Asikainen T, et al. European all-cause excess and influenza-attributable mortality in the 2017/18 season: should the burden of influenza B be reconsidered? Clin Microbiol Infect. 2019;25(10):1266-76. https://doi.org/10.1016/j. cmi.2019.02.011.

58. Suman G, Prajapati D. Control chart applications in healthcare: a literature review. Int J Metrol Qual Eng. 2018;9 https://doi.org/10.1051/ijmqe/2018003

59. van der Worp B, Sandset EC, Dichgans M, Caso V. Likely increase in the risk of death or disability from stroke during the COVID-19 pandemic. The European Stroke Organisation (ESO) cautions against the consequences of the coronavirus-crisis on stroke care. [Internet]. Basel, Switzerland: European Stroke Organisation; 2020 [cited 2021 June 8]. Available from: https://eso-stroke.org/ likely-increase-in-the-risk-of-death-or-disability-fromstroke-during-the-covid-19-pandemic/

60. Hajdu SD, Pittet V, Puccinelli F, Ben Hassen W, Ben Maacha M, Blanc R, et al. Acute stroke management during the COVID-19 pandemic: does confinement impact eligibility for endovascular therapy? Stroke. 2020;51(8):2593-6. https://doi.org/10.1161/strokeaha. 120.030794 .

61. Kerleroux B, Fabacher T, Bricout N, Moïse M, Testud B, Vingadassalom S, et al. Mechanical thrombectomy for acute ischemic stroke amid the COVID-19 outbreak: decreased activity, and increased care delays. Stroke. 2020;51(7):2012-7. https://doi.org/10.1161/strokeaha. 120.030373 . 
62. McConachie D, McConachie N, White P, Crossley R, Izzath W. Mechanical thrombectomy for acute ischaemic stroke during the COVID-19 pandemic: changes to UK practice and lessons learned. Clin Radiol. 2020;75(10):795.e7-795.e13. https://doi.org/10.1016/j. crad.2020.07.001.

63. Okano Y, Ishimatsu K, Kato Y, Yamaga J, Kuwahara K, Okumoto K, et al. Clinical features of stroke mimics in the emergency department. Acute Med Surg. 2018;5(3):2418. https://doi.org/10.1002/ams2.338.

64. McMeekin P, White P, James MA, Price CI, Flynn D, Ford GA. Estimating the number of UK stroke patients eligible for endovascular thrombectomy. Eur Stroke J. 2017;2(4):319-26.

65. Chia NH, Leyden JM, Newbury J, Jannes J, Kleinig TJ. Determining the number of ischemic strokes potentially eligible for endovascular thrombectomy: a population-based study. Stroke. 2016;47(5):1377-80. https://doi.org/10.1177/2396987317733343.

66. Rai AT, Seldon AE, Boo S, Link PS, Domico JR, Tarabishy AR, et al. A population-based incidence of acute large vessel occlusions and thrombectomy eligible patients indicates significant potential for growth of endovascular stroke therapy in the USA. J Neurointerv Surg. 2017;9(8):722-6. https://doi.org/10.1136/neuri ntsurg-2016-012515.

Publisher's note Springer Nature remains neutral with regard to jurisdictional claims in published maps and institutional affiliations. 